\title{
Intelligent system based comparative analysis study of SARS-CoV-2 spike protein and antigenic proteins in different types of vaccines
}

\author{
Rabeb Touati ${ }^{1,2}$ and Ahmed A. Elngar ${ }^{3,4^{*}}$ (I)
}

\begin{abstract}
Background: Coronaviruses, members of the Coronavirinae subfamily in the Coronaviridae family, are enveloped and positive-stranded RNA viruses that infect animals and humans, causing intestinal and respiratory infections. Coronavirus disease 2019 (COVID-19) is caused by a novel coronavirus, named Severe Acute Respiratory Syndrome Coronavirus 2 (SARS-CoV-2). This disease appeared, for the first time (December 2019), in China and has spread quickly worldwide causing a large number of deaths. Considering the global threat, the World Health Organization (WHO) has declared, in March 2020, COVID-19 as a pandemic. Many studies suggest the great effect of the existing vaccines to protect against symptomatic cases of death by the COVID-19 virus. This paper, proposes to compare the main antigenic proteins sequences of the existing vaccines with Spike (S) protein of the SARS-CoV-2 genome. Our choice of $S$ protein is justified by the major role that plays it in the receptor recognition and membrane fusion process based on an intelligent system. Herein, we focus on finding a correlation between $\mathrm{S}$ protein and compulsory vaccines in the countries that have a less death number by COVID-19 virus. In this work, we have used a combination of coding methods, signal processing, and bioinformatic techniques with the goal to localize the similar patterns between the $S$ gene of the SARS-Cov-2 genome and 14 investigated vaccines.

Results: A total of 8 similar sequences which have a size more than 6 amino acids were identified. Further, these comparisons propose that these segments can be implicated in the immune response against COVID-19, which may explain the wide variation by country in the severity of this viral threat.
\end{abstract}

Conclusions: Our in silico study suggests a possible protective effect of Poliovirus, HIB, Hepatitis B, PCV10, Measles, Mumps, and Rubella (MMR) vaccines against COVID-19.

Keywords: Coronavirus, Vaccines, Poliovirus, HIB, Hepatitis B, And PCV10, COVID-19, Genome signature, Genomic coding techniques

\section{Background}

Since December 2019, COVID-19, caused by the novel coronavirus SARS-CoV-2, has spread to more than 223 countries to date causing huge health and economic

\footnotetext{
*Correspondence: elngar_7@yahoo.co.uk

${ }^{3}$ Faculty of Computers and Artificial Intelligence, Beni-Suef University,

Slah Salem Str., 62511 Beni-Suef City, Egypt

Full list of author information is available at the end of the article
}

crisis [1-3]. The genome of SARS-CoV-2, like other families of Coronaviruses (CoVs), is an enveloped positive-sense single-stranded RNA virus. It belongs to the Coronaviridae family, the Orthocoronavirinae subfamily and the Betacoronavirus genus [1-3]. Coronaviruses $(\mathrm{CoVs})$ can mainly infect mammals by Alpha $(\alpha)$ or Beta $(\beta)$ coronaviruses, and predominantly can infect birds by Gamma $(\gamma)$ or Delta $(\delta)$ Coronaviruses $[4,5]$. The SARS$\mathrm{CoV}-2$ viral genome of 29,903 nucleotides, approximately, 
contains 5'and 3' untranslated regions and 11 Open Reading Frames (ORFs) encoding 11 proteins including the $S$ protein [6]. Probably, the modes of SARS-Cov-2 transmission among humans are via three primary pathways: inhaling respiratory droplets directly from infected persons, or contact with infected environmental surfaces know as "fomites" and touching your mucous membranes with soiled hands, or inhaling infected airborne particles. Recent researches indicate a high correlation between the SARS-COV-2 genome and the two genomes of the batCoV RaTG13 and the pangolin-CoV MP789 followed by two other genomes: CoVZC45 and CoVZXC21 [7, 8].

The outbreak of SARS-CoV-2 caused 2,797,435 deaths with a total of 127,847,262 confirmed cases (December 20, 2019 to March 29, 2021) that have variable damages from one country to another. In the majority of cases, huge damages were reported, such as in the USA, Brazil, and India causing respectively 562,526, 312,299 and 161,881 , deaths as well as $30,962,803,12,534,688$, and $12,039,644$ confirmed cases up to 29 March 2020 [9] Nevertheless, in other regions, such as, Laos, Vietnam, and Finland damages seem to be limited and the number of deaths, respectively, did not exceed 0, 35, and 822 [9]. However, for other regions, like, Nicaragua, Sierra Leone, Vietnam, and Madagascar, cases and damages seem to be limited and the number of deaths, respectively, did not exceed three hundred cases. These temporal variances in a number of case fatality rates can be caused by different factors: political and economic strategies, cultural behavior, age, and also health infrastructure, $[10,11]$. Furthermore, the population's immunological background is probably due to the vaccination strategies used in these countries [11-15]. From another point of view, different vaccines such as BCG (Bacillus Calmette-Guérin), OPV (Oral Poliovirus Vaccine), and MMR (Measles, Mumps, and Rubella vaccines) demonstrated an immune response to fight various pathogens $[12,14,16,17]$.

On the other hand, these different variations may be attributed to the adoption of a universal and long-standing BCG as again found to be very significantly protective for whom vaccination records were available $[11,18$, 19]. In addition, the MMR vaccine protective potential was investigated based on S protein bioinformatic analysis [20]. Based on this computational biology analysis, the MMR vaccine was investigated as being potentially protective for adults and provides advantageous protection for children against COVID-19 as well. However, experimental analysis is required. Furthermore, pneumococcal vaccination PCV13 was again found to be very efficient in a study of 137,037 individuals who received SARS-CoV-2 PCR tests [21]. A recent study proves great similarities between the SARS-CoV-2 genome and pneumococcal vaccines PspA and PspC [22]. Indeed, other researchers found that polio, Hemophilus influenzae type-B (HIB), varicella, geriatric flu, MMR, PCV13, and hepatitis A / B (HepA-HepB) vaccines administered in the past 1,2 , and 5 years are associated with decreased SARS-CoV- 2 infection rates $[22,23]$.

In this work, we propose in silico study to investigate the potential protective effect of 14 investigated vaccines (Bordetella Pertussis, Tetanus, Haemophilus influenzae type B (Hib), Corynebacterium Diphtheriae, Streptococcus pneumoniae, Hepatitis A, and Hepatitis B) against COVID-19. We aim to localize similar amino acid (aa) regions in the $\mathrm{S}$ protein of the SARS-CoV-2 genome and the main antigenic proteins in other vaccines which may lead to the production of cross-reactive antibodies against the target viruses as well as SARS-CoV-2. To achieve this goal, we used a combination of bioinformatics, and signal processing tools to identify the common amino-acid (aa) sequences of the main antigenic protein of SARS-CoV-2 and investigated vaccines.

\section{Methods}

Recent research [7] has been suggested the SARS-Cov-2 genome shares $96 \%$ genetic similarity with a RATG13 coronavirus genome and $86 \%$ genetic similarity with the pangolin coronavirus genome. Subfigure (a) of Fig. 1 presents the distribution of nucleotide modifications by percentage along the SARS-COV-2 region compared to the RATG13 and the MP789 coronavirus genomes. Spike protein presents high recombination between RATG13 and the MP789 coronavirus genomes as shown in subfigure (a) of Fig. 1. Specifically in the position 1251 to 1600 base pairs, the total nucleotide mutation is equal to $14.28 \%$ (50 nucleotides) between the two coronavirus genomes (the pangolin and the SARS-CoV-2). These mutations are less than the mutation located between bat coronavirus and SARS -CoV-2 S gene (35\% and 125 modified nucleotides). This research [7] suggests that the SARS-CoV-2 genome is the result of recombination events between two coronavirus genomes: The bat-CoV RATG13 and the pangolin-CoV MP789.

Figure 2 presents the Flowchart diagram of our adopted localization methodology to find similar amino acid sequences between SARS-CoV-2 genome and our investigated sequences. Here we have used the recombination between bioinformatics techniques and signal processing tools.

\subsection{Vaccines and Sequences investigated (databak accession numbers)}

Our study is focused on the vaccines included in one of the countries presenting a very low number of confirmed COVID-19 cases. Our investigated vaccines include main old and more recent vaccines (a number 


\section{(a)}

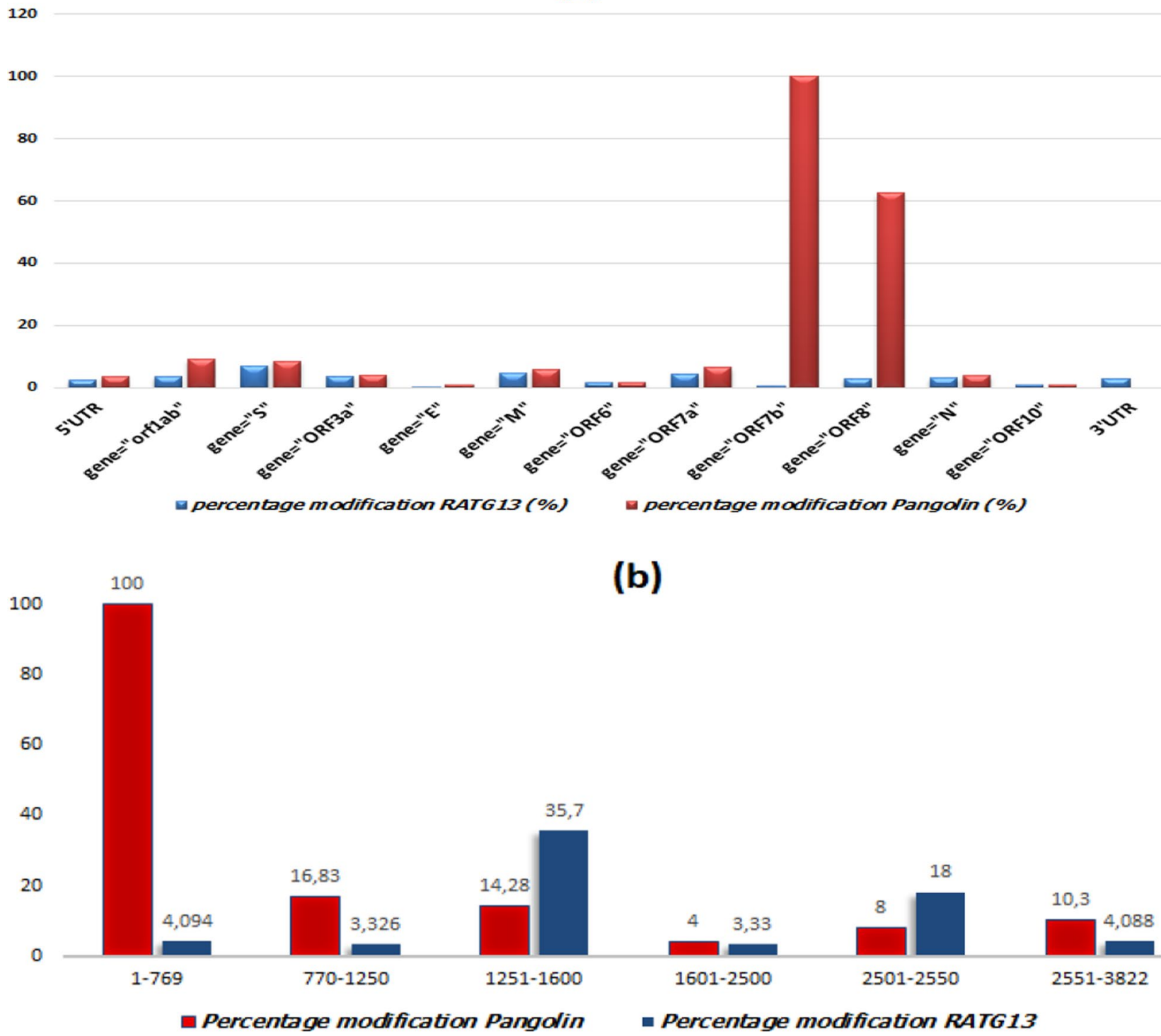

Fig. 1 Percentage of nucleotide modifications of Sars-Cov-2 genome comparing to RATG13 and MP789 genomes [7]: a Percentage of nucleotide modifications of SARS-CoV-2 genome comparing to RATG13 and Pangolin genomes; $\mathbf{b}$ percentage of nucleotide modifications of S gene of SARS-CoV-2 genome comparing to the $S$ genes of RATG13 and Pangolin genomes [7]

equal to 14) with 34 protein sequences: BCG, Poliovirus, Measles, Mumps, Corynebacterium diphtheria, Tetanus, and Bordetella pertussis vaccines and more recent vaccines against hepatitis B and A viruses, Rubella virus, Hemophilus influenzae type B (Hib) and Streptococcus pneumoniae (PCV10, pspC, protein PspC, Protein A) [24]. The amino-acid sequences of these antigenic proteins $(n=34)$ constituting those vaccines as well as the amino acid sequence of Spike protein of the Wuhan Sars-Cov-2 genome strain were obtained from the database NCBI Genbank (https:// www.ncbi.nlm.nih.gov). Accession numbers are presented in Table 1.

\subsection{Amino acid sequence alignment and hot spot analysis}

We aim to detect similar amino-acid (aa) sequences between protein sequences. The presented results were obtained using Blastp program. This program can detect identical amino-acids and, or similar amino-acids of two genomic sequences. These results were presented using BioEdit software (version 7.2.5) (http://www.mybio software.com/bioedit-7-0-9-biological-sequence-align 


\section{NCBI database}

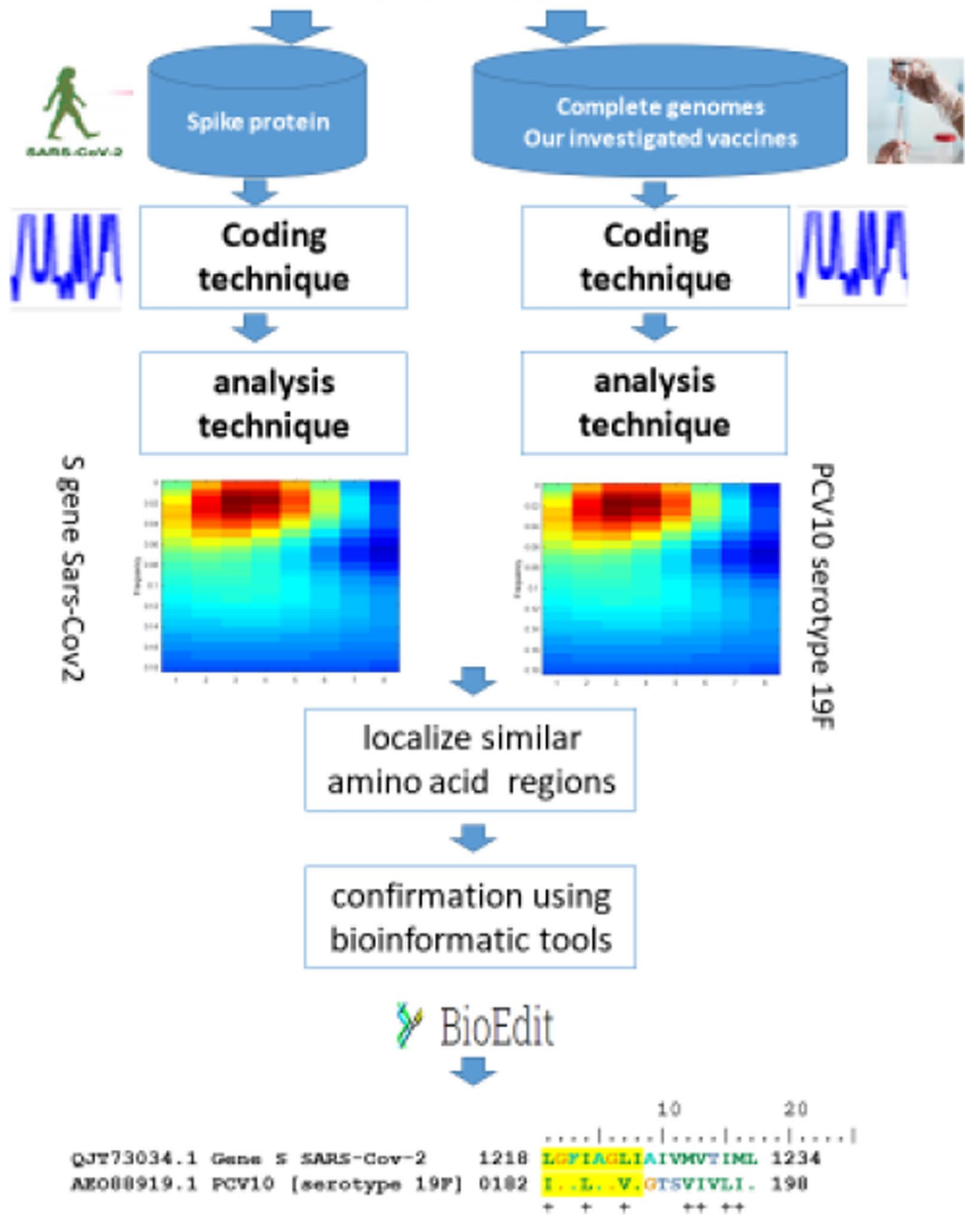

Fig. 2 Flowchart diagram of methodology to localize the similarities between two amino acid sequences 
Table 1 Investigated vaccines and their corresponding antigenic proteins obtained from NCBI Genbank (https://www.ncbi.nlm.nih. gov)

\begin{tabular}{|c|c|c|c|c|c|c|c|}
\hline & Vaccine & Protein & Accession $\mathrm{N}^{\circ}$ & & Vaccine & Protein & Accession $\mathrm{N}^{\circ}$ \\
\hline 1 & Tetanus & Toxin protein & AAA23282.1 & \multirow[t]{2}{*}{11} & \multirow{2}{*}{$\begin{array}{l}\text { Hemophilus influenzae } \\
\text { serotype B (Hib) }\end{array}$} & Capsulation protein & CWW30252.1 \\
\hline 2 & $\begin{array}{l}\text { Corynebacterium diph- } \\
\text { theriae }\end{array}$ & Toxin protein & CAA00374.1 & & & $\begin{array}{l}\text { Capsular polysaccharide } \\
\text { biosynthesis protein }\end{array}$ & WP_015702013.1 \\
\hline \multirow[t]{2}{*}{3} & \multirow[t]{2}{*}{ Hepatitis B } & HBsAg-adw2 & AAW65557.1 & \multirow[t]{2}{*}{12} & \multirow[t]{2}{*}{ Poliovirus } & $\begin{array}{l}\text { VP1 protein: Sabin } 1 \\
\text { strain }\end{array}$ & AAL89597.1 \\
\hline & & HBsAg-adr & AAW65588.1 & & & $\begin{array}{l}\text { VP1 protein: Sabin } 2 \\
\text { strain }\end{array}$ & AAL92486.1 \\
\hline 4 & Bordetella pertussis & Toxin protein & AQW64178.1 & & & $\begin{array}{l}\text { VP1 protein: Sabin } 3 \\
\text { strain }\end{array}$ & AAL89592.1 \\
\hline \multirow[t]{2}{*}{5} & \multirow[t]{2}{*}{ Mumps } & $\begin{array}{l}\text { Hemagglutinin/neu- } \\
\text { raminidase protein }\end{array}$ & ACN50032.1 & \multirow[t]{2}{*}{13} & \multirow[t]{2}{*}{$\begin{array}{l}\text { Streptococcus pneumo- } \\
\text { niae (PCV10) }\end{array}$} & $\begin{array}{l}\text { Capsular polysac- } \\
\text { charide/biosynthesis } \\
\text { protein (serotype 1) }\end{array}$ & COS99248.1 \\
\hline & & Fusion protein & ACN50030.1 & & & $\begin{array}{l}\text { Capsular polysac- } \\
\text { charide/biosynthesis } \\
\text { protein (serotype 4) }\end{array}$ & AAK20668.1 \\
\hline 6 & Rubella & Polyprotein E1/E2 & ACN50046.1 & & & $\begin{array}{l}\text { Capsular polysac- } \\
\text { charide/biosynthesis } \\
\text { protein (serotype 5) }\end{array}$ & CAl32793.1 \\
\hline \multirow[t]{2}{*}{7} & \multirow[t]{2}{*}{ Hepatitis A } & VP1 protein & AAA45466.1 & & & $\begin{array}{l}\text { Capsular polysac- } \\
\text { charide/biosynthesis } \\
\text { protein (serotype 6B) }\end{array}$ & AAK20683.1 \\
\hline & & VP3 protein & AAA45466.1 & & & $\begin{array}{l}\text { Capsular polysac- } \\
\text { charide-biosynthesis } \\
\text { protein (serotype 7F) }\end{array}$ & CAl32924.1 \\
\hline \multirow[t]{2}{*}{8} & \multirow[t]{2}{*}{ Measles } & Fusion protein & AAF85704.1 & & & $\begin{array}{l}\text { Capsular polysac- } \\
\text { charide/ biosynthesis } \\
\text { protein (serotype 9V) }\end{array}$ & CAl33023.1 \\
\hline & & Hemagglutinin protein & AAF85705.1 & & & $\begin{array}{l}\text { Capsular polysac- } \\
\text { charide/ biosynthesis } \\
\text { protein (serotype 14) }\end{array}$ & CAl33319.1 \\
\hline \multirow[t]{3}{*}{9} & \multirow[t]{3}{*}{$\begin{array}{l}\text { Bacillus Calmette-Guérin } \\
(B C G)\end{array}$} & $\begin{array}{l}\text { Immunogenic protein } \\
\text { MPB64 }\end{array}$ & AIC33023.1 & & & $\begin{array}{l}\text { Capsular polysac- } \\
\text { charide/ biosynthesis } \\
\text { protein (serotype 18C) }\end{array}$ & CAl33577.1 \\
\hline & & $\begin{array}{l}\text { Immunogenic protein } \\
\text { MPB70 }\end{array}$ & BAA07402.1 & & & $\begin{array}{l}\text { Capsular polysaccharide } \\
\text { biosynthesis protein } \\
\text { (serotype 19F) }\end{array}$ & AEO88919.1 \\
\hline & & $\begin{array}{l}\text { Immunogenic protein } \\
\text { MPB83 }\end{array}$ & BAA11027.1 & & & $\begin{array}{l}\text { Capsular polysac- } \\
\text { charide/ biosynthesis } \\
\text { protein (serotype 23F) }\end{array}$ & AAC69522.1 \\
\hline \multirow[t]{3}{*}{10} & \multirow{3}{*}{$\begin{array}{l}\text { Streptococcus Pneumo- } \\
\text { niae; } \\
\text { Pneumococcal Surface } \\
\text { Protein A }\end{array}$} & PspA Q9LAZ1 & AAF27700.1 & \multirow[t]{3}{*}{14} & \multirow{3}{*}{$\begin{array}{l}\text { Streptococcus Pneumo- } \\
\text { niae; } \\
\text { pspC, Pneumococcal } \\
\text { Surface protein PspC }\end{array}$} & \multirow[t]{3}{*}{ Q9KK40 } & \multirow[t]{3}{*}{ AAF73787.1 } \\
\hline & & PspA 034097, pspA, & AAC62252.1 & & & & \\
\hline & & PspA Q9LAY4 & AAF27707.1 & & & & \\
\hline
\end{tabular}

ment-editor.html). Figure 3 presents an example of our obtained results after comparing the $\mathrm{S}$ protein of the Sars-Cov- 2 genome and two sequences of the tetanus vaccine. These obtained results present different similar patterns with their position in each genome.

\subsection{Numerical mapping of amino acid sequences}

The conversion of the genomic sequences into numerical ones using signal processing tools is an important step to characterize the unknown region [25-28]. It allows rapid image observation of similar patterns 


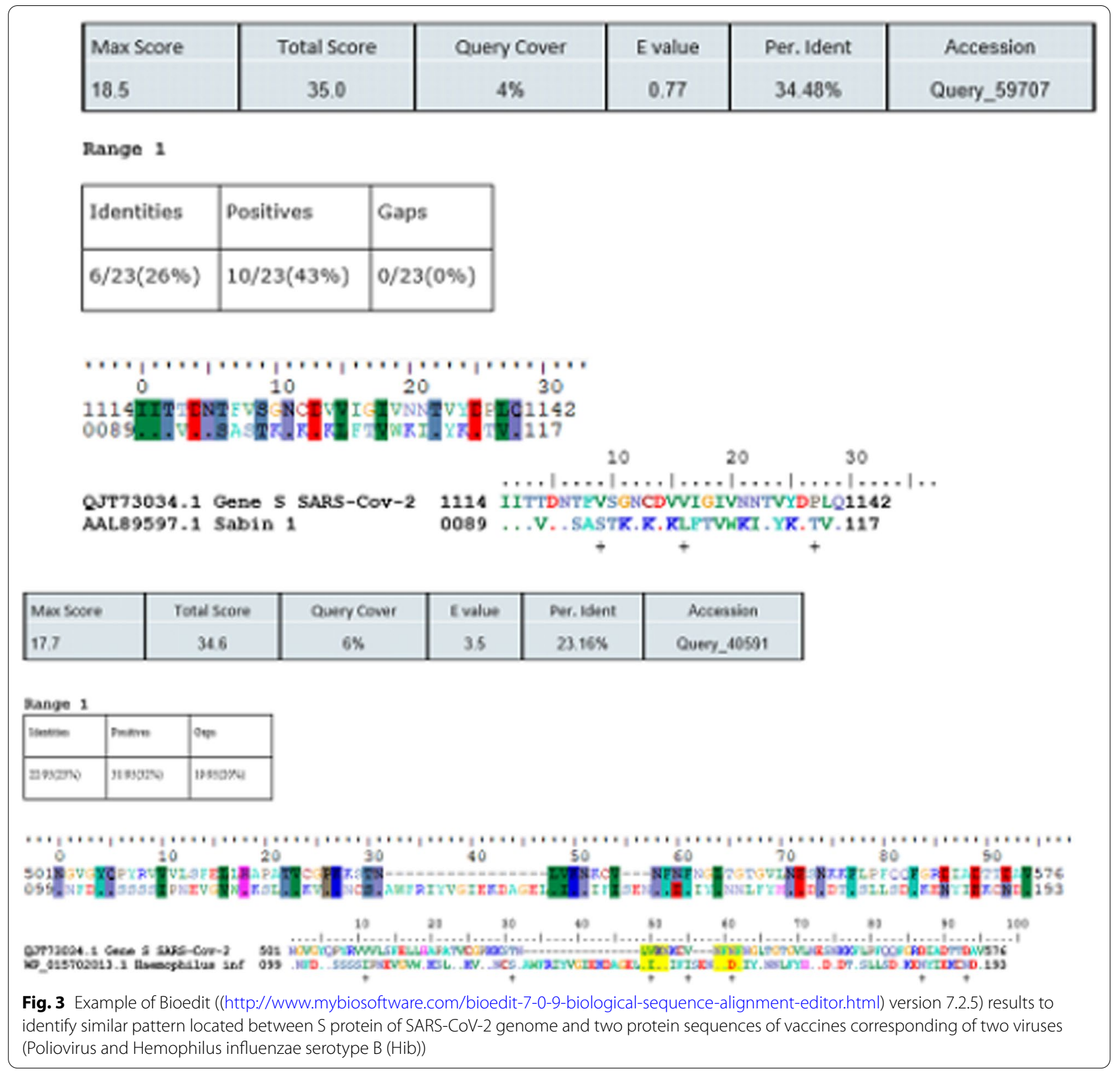

before assessing more precise analysis. By applying the Electron-Ion Interaction Potential (EIIP) coding technique, we can obtain for each protein sequence a signal. This type of coding technique (EIIP) has been used to transform the amino acid (aa) sequence into numerical representation [25]. For that, we converted our aminoacid sequences into numerical ones using the following
Table 2, where each amino acid was represented by its corresponding value of the EIIP coding technique.

Figure 4 shows the 1-D signal representation of protein sequence corresponding to 150 amino acids of S-protein of Sars-Cov-2 genome. Each signal value corresponds to an amino acid position in the protein sequence. 
Table 2 EIIP coding technique for transformation of the amino acid sequence into a signal

\begin{tabular}{llllll}
\hline Amino acid & $\begin{array}{l}\text { Single } \\
\text { letter } \\
\text { symbol }\end{array}$ & ElIP & Amino acid & $\begin{array}{l}\text { Single } \\
\text { letter } \\
\text { symbol }\end{array}$ & EIIP \\
\hline Ala & A & 0.0373 & Leu & L & 0 \\
Arg & R & 0.0959 & Lys & K & 0.0371 \\
Asn & N & 0.0036 & Met & M & 0.0823 \\
Asp & D & 0.1263 & Phe & F & 0.0946 \\
Cys & C & 0.0829 & Pro & P & 0.0198 \\
Gln & Q & 0.0761 & Ser & S & 0.0829 \\
Glu & E & 0.0058 & Thr & T & 0.0941 \\
Gly & G & 0.005 & Trp & W & 0.0548 \\
His & H & 0.0242 & Tyr & Y & 0.0516 \\
lle & I & 0 & Var & V & 0.0057 \\
\hline
\end{tabular}

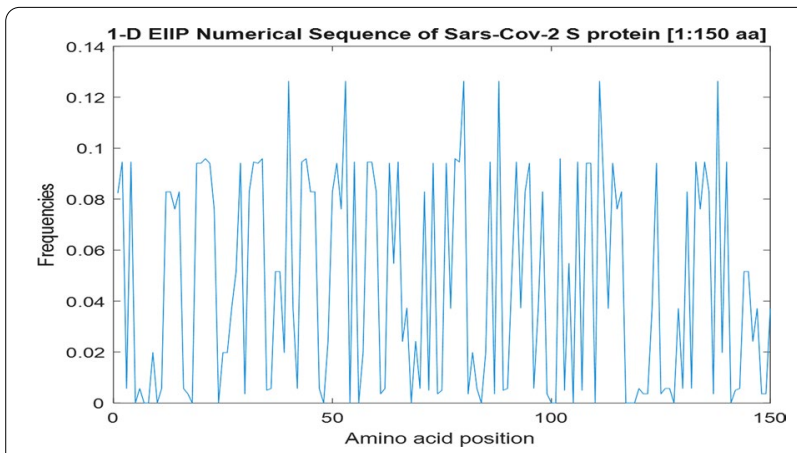

Fig. 4 ElIP Numerical representation (generated signal) of 150 amino acids of Sars-Cov-2 Spike protein

After transforming the amino-acid sequence into a signal, we aimed to see it in a 2-D representation to focus more on the information that can contain. The Continuous Wavelet Transform (CWT) (along 64 scales with $\left.w_{0} \sim 5.5\right)$ was applied to protein signal to obtain a protein image (2-D scalogram) [27, 28].

$$
w_{0}=2 * \pi * f_{0}
$$

$w_{0}$ corresponds to the oscillations number of wavelet transform, and the parameter $\mathrm{f}_{0}$ is the central frequency of the basic wavelet. These images (wavelet scalograms) are the best method to detect the homologous regions between two amino-acid sequences [27, 28].

\section{Results}

\subsection{Numerical mapping}

To transform a protein sequence into numerical ones, we need to apply a coding technique to have a signal and an analysis technique to have an image.

In this work, and after applying different methods, we have chosen to use the EIIP as a coding technique and the wavelet analysis as an analysis technique. After applying the EIIP coding technique and CWT of an amino acid sequence, we obtained a scalogram image (modulo of the matrix contains CWT coefficients). The amino acid scalograms (2D) are the best way to see the similarities between two sequences if it exists. As a result, we obtained two similar patterns (scalograms) that confirm these similarities. Figure 5 presents images corresponding to similar patterns between the region of $\mathrm{S}$ protein of Wuhan SARS-CoV-2 genome and some regions of our investigated amino-acid sequences.

\subsection{Alignment of amino acid sequences}

As a result, similar segments (4-8 aa) between the $S$ protein of the SARS-Cov-2 genome and our investigated vaccine antigenic proteins were identified (Fig. 6 and Table 3). Only antigenic protein included in Hepatitis B, Hib, Poliovirus, PCV10 vaccines showed 6 to 8 similar consecutive amino-acids. The corresponding motifs are indicated in Table 3. PCV10 antigenic proteins shared 2 similar motifs (LGFIAGLI / NSVAYS) of 8 and 6 amino acids.

Figure 6 contains 23 similar patterns corresponding to more of 4 similar consecutive amino-acids of the $\mathrm{S}$ protein and our investigated vaccines. A total of 11 similar patterns have a size equal or more than 6 amino acids were identified.

Table 3 presents the total repetition number of each similar pattern that was identified between vaccine and $S$ protein of Sars-Cov-2 genome.

To more see if these patterns are present in the other genes of the SARS-Cov-2 genome, we were also able to map and compare all other SARS-CoV-2 genes with our investigated vaccines. We confirm that these presented similar patterns (PGTNTSN,LGFIAGLI,NSVAYS , andLDPLSE) between the Sars-Cov-2 S gene and vaccines are not presented in the other genes of the Sars-Cov-2 genome. Moreover, we detect a new similar pattern 'VFLLVT' between the BCG vaccine and SarsCov-2N gene (Fig. 7). 


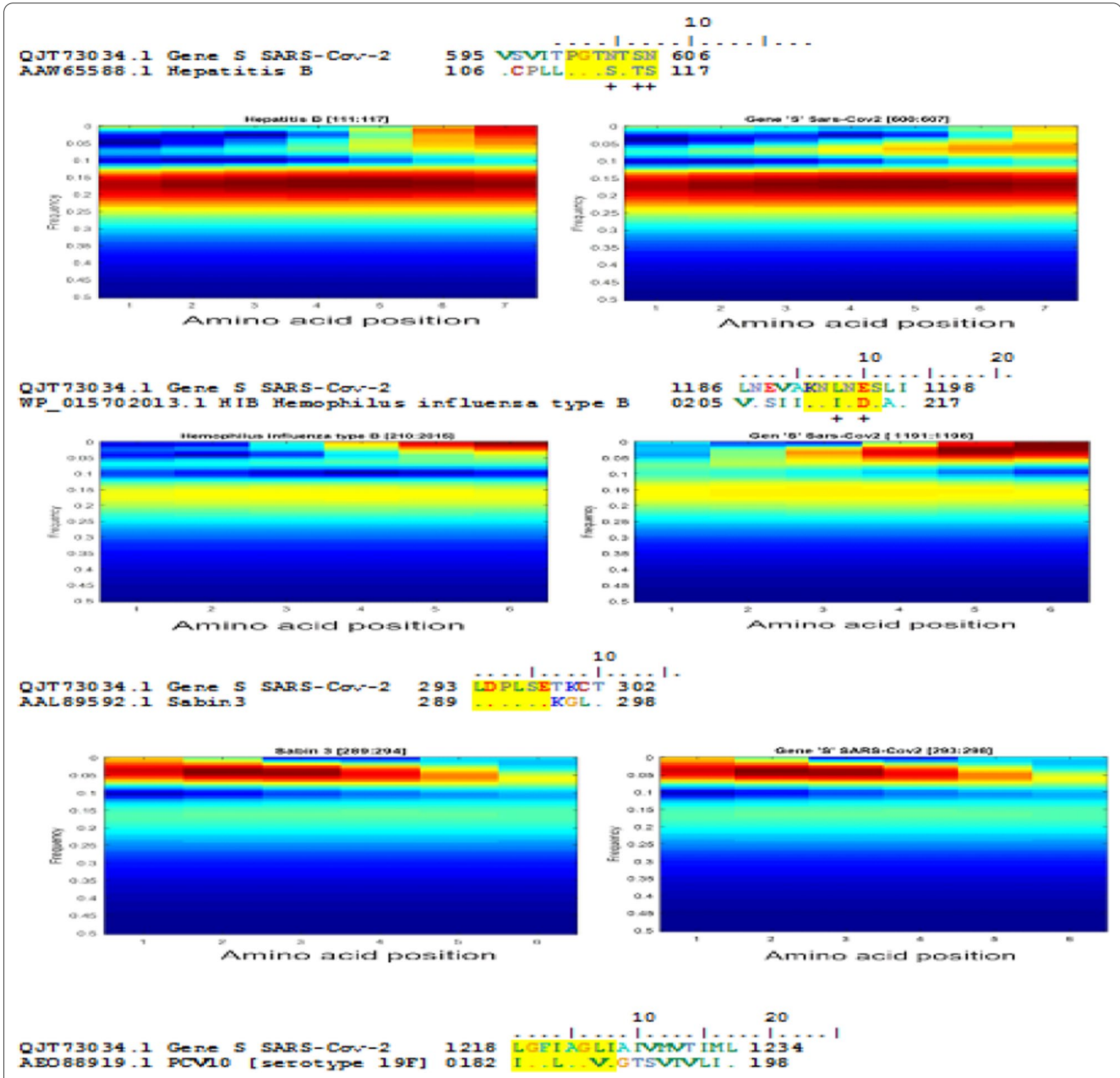

Fig. 5 Wavelet representation (Scalograms) of similar regions (patterns) of amino acid region of SARS-COV-2 S gene (QJT73034.1) compared with the acid amino vaccines; the first column shows the $S$ gene of the SARS-cov-2 genome and the second shows the vaccine sequence

\section{Discussion}

Different researchers prove that the Sars-Cov-2 genome is the result of the recombination between two beta-coronavirus genomes: Pangolin and Bat coronavirus [7, 8, 29, 30]. Various in silico studies search for the effect of the vaccination, especially with pneumococcal vaccines, to protect against symptomatic cases of SARS-CoV-2 infection and death [31-36]. Our main objective was to find similar amino-acid sequences in the $\mathrm{S}$ protein of the SarsCov-2 genome and the investigated proteins sequences 


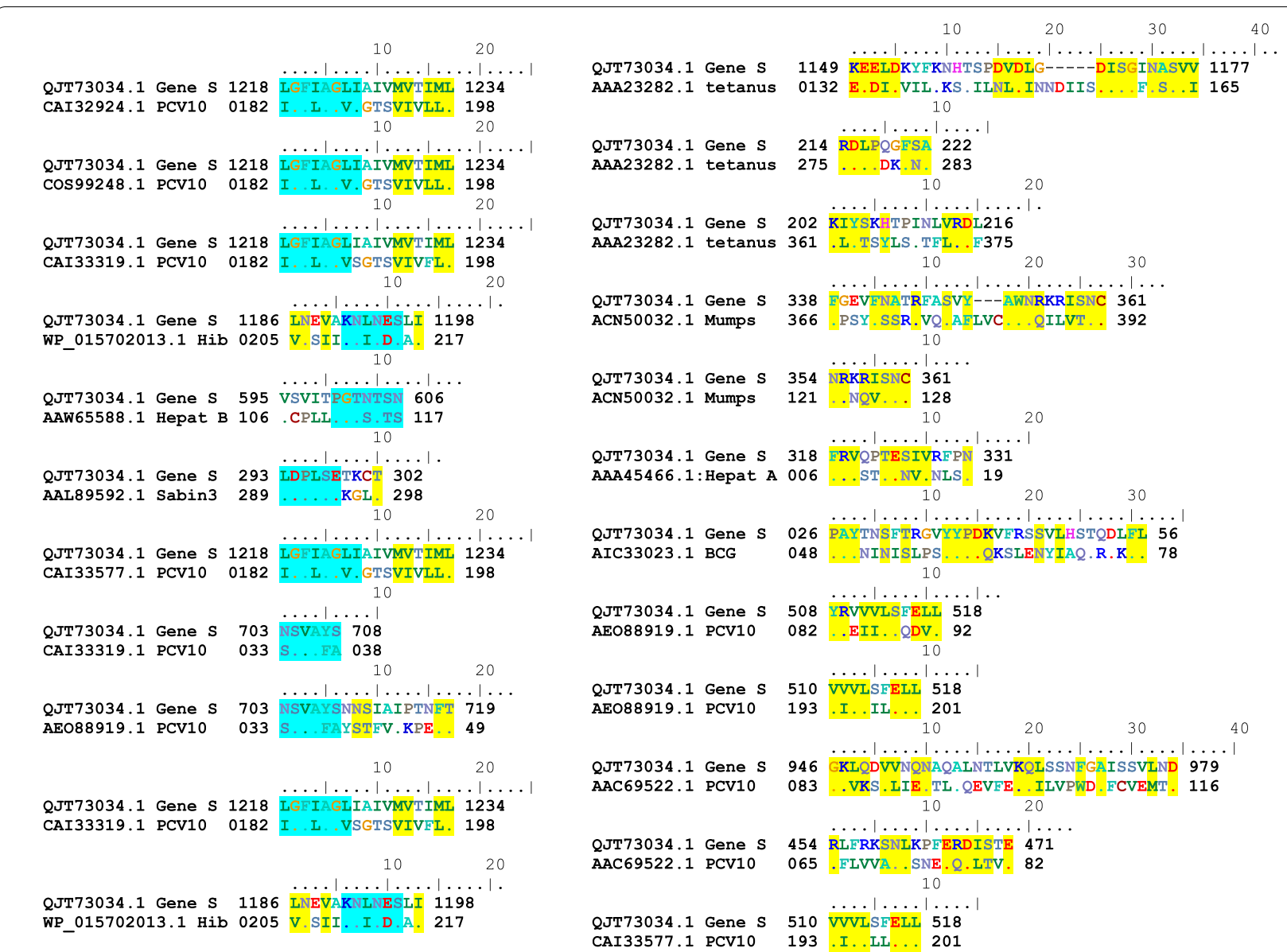

Fig. 6 Highly similar sequences were identified in our investigated vaccines and SARS-CoV-2 proteins using BioEdit software (http://www.mybio software.com/bioedit-7-0-9-biological-sequence-alignment-editor.html)

mentioned above using the recombination between bioinformatics and signal processing tools. This study using an intelligent system suggests the possible influence of Hepatitis B, Hib, Poliovirus, Tetanus, and PCV10 vaccines in protecting against COVID-19. In addition, this work could explain the variation in the number of deaths among countries and the possibility that these vaccines contain antigens that might be cross-reactive with SARS-CoV-2. For this, we consider that some of these investigated vaccines as real supportive protective measures in the fight against the COVID-19 pandemic. A recent review [37] presents a comparative table that contains multiple vaccine platforms and has been explored to develop the COVID-19 vaccine. Each vaccine platform has unique advantages and disadvantages. Most of these vaccines use either the Spike protein or its receptor-binding domain (RBD) as the antigen. 
Table 3 Results of total similar patterns number were identified in our investigated vaccines and SARS-CoV-2 proteins

\begin{tabular}{|c|c|c|c|c|c|}
\hline Vaccine & Protein & $\%$ Identity & $\begin{array}{l}\text { Number of similar } \\
\text { patterns less than } 6 \text { aa } \\
\text { and more or equal to } 2\end{array}$ & $\begin{array}{l}\text { Number of similar } \\
\text { patterns more or equal } \\
\text { to } 6 \mathrm{aa}\end{array}$ & Pattern more than 6 aa \\
\hline Tetanus & Tetanus toxin protein & 35.29 & 47 & 0 & - \\
\hline $\begin{array}{l}\text { Corynebacterium diph- } \\
\text { theriae }\end{array}$ & Diptheria toxin protein & 45.00 & 11 & 0 & - \\
\hline \multirow[t]{2}{*}{ Hepatitis B } & HBsAg-adw2 & 55.56 & 5 & 0 & - \\
\hline & HBsAg-adr & 50.00 & 5 & 1 & PGTNTSN \\
\hline Bordetella pertussis & $\begin{array}{l}\text { Bordetella pertussis toxin } \\
\text { protein }\end{array}$ & 23.26 & 6 & 0 & - \\
\hline \multirow[t]{2}{*}{ Measles } & $\begin{array}{l}\text { Measles hemagglutinin } \\
\text { protein }\end{array}$ & 23.75 & 4 & 0 & - \\
\hline & Measles fusion protein & 45.45 & 2 & 0 & - \\
\hline Rubella & Rubella polyprotein E1/E2 & NONE & - & - & - \\
\hline \multirow[t]{2}{*}{ Mumps } & Mumps xxx protein & 31.43 & 9 & 0 & - \\
\hline & $\begin{array}{l}\text { Mumps hemagglutinin/ } \\
\text { neuraminidase protein }\end{array}$ & 27.14 & 32 & 0 & - \\
\hline \multirow[t]{2}{*}{ Hepatitis A } & Hepatovirus A VP1 protein & 34.29 & 22 & 0 & - \\
\hline & Hepatovirus A VP3 protein & 50.00 & 2 & 0 & - \\
\hline \multirow[t]{3}{*}{$\begin{array}{l}\text { Bacille Calmette-Guérin } \\
(\mathrm{BCG})\end{array}$} & $\begin{array}{l}\text { Immunogenic protein } \\
\text { MPB83 }\end{array}$ & 27.27 & 2 & 0 & - \\
\hline & $\begin{array}{l}\text { Immunogenic protein } \\
\text { MPB70 }\end{array}$ & 52.17 & 4 & 0 & - \\
\hline & $\begin{array}{l}\text { Immunogenic protein } \\
\text { MPB64 }\end{array}$ & 35.48 & 10 & 0 & - \\
\hline \multirow{2}{*}{$\begin{array}{l}\text { Hemophilus influenzae } \\
\text { type B (Hib) }\end{array}$} & Capsulation protein & 25.00 & 5 & 0 & - \\
\hline & $\begin{array}{l}\text { Capsular polysaccharide } \\
\text { biosynthesis protein }\end{array}$ & 23.16 & 7 & 1 & KNLNES \\
\hline \multirow[t]{3}{*}{ Poliovirus } & $\begin{array}{l}\text { VP1 protein (Sabin } 1 \\
\text { strain) }\end{array}$ & 34.48 & 7 & 0 & - \\
\hline & $\begin{array}{l}\text { VP1 protein (Sabin } 2 \\
\text { strain) }\end{array}$ & 42.11 & 4 & 0 & - \\
\hline & $\begin{array}{l}\text { VP1 protein (Sabin } 3 \\
\text { strain) }\end{array}$ & 26.67 & 0 & 1 & LDPLSE \\
\hline
\end{tabular}

For this, we studied the effect of our investigated vaccines and see if it can be implicated to boost our immune system against COVID-19. We investigate the possibility of the protection against COVID-19 through inducing a cross-reactive antibody by different existing vaccines. To achieve this goal, we used a combination of bioinformatic and signal processing tools to compare the amino-acid sequences of the main S protein of SARS-CoV-2 genome and our investigated vaccines. A numerical mapping showed two similar patterns corresponding to an exposed site have a size of 7 and 8 amino-acids: 'PGTNTSN' detected in HBsAg-of Hepatitis B vaccine and 'LGFIAGLI' detected in PCV10 vaccine. Two other patterns ('NSVAYS' and 'LDPLSE') in two investi- 
Table 3 (continued)

\begin{tabular}{|c|c|c|c|c|c|}
\hline Vaccine & Protein & $\%$ Identity & $\begin{array}{l}\text { Number of similar } \\
\text { patterns less than } 6 \text { aa } \\
\text { and more or equal to } 2\end{array}$ & $\begin{array}{l}\text { Number of similar } \\
\text { patterns more or equal } \\
\text { to } 6 \text { aa }\end{array}$ & Pattern more than 6 aa \\
\hline \multirow[t]{10}{*}{$\begin{array}{l}\text { Streptococcus pneumoniae } \\
\text { (PCV10) }\end{array}$} & $\begin{array}{l}\text { Capsular polysaccharide } \\
\text { biosynthesis protein } \\
\text { [serotype 19F] }\end{array}$ & 23.15 & 18 & 2 & LGFIAGLI/ NSVAYS \\
\hline & $\begin{array}{l}\text { Capsular polysaccharide } \\
\text { biosynthesis protein } \\
\text { [serotype } 23 \mathrm{~F} \text { ] }\end{array}$ & 26.47 & 6 & 0 & - \\
\hline & $\begin{array}{l}\text { Capsular polysaccharide } \\
\text { biosynthesis protein } \\
\text { [serotype } 18 C \text { ] }\end{array}$ & 35.29 & 15 & 2 & LGFIAGLI/ NSVAYS \\
\hline & $\begin{array}{l}\text { Capsular polysaccharide } \\
\text { biosynthesis protein } \\
\text { [serotype 14] }\end{array}$ & 27.38 & 29 & 2 & NSVAYS /LGFIAGL \\
\hline & $\begin{array}{l}\text { Capsular polysaccharide } \\
\text { biosynthesis protein } \\
\text { [serotype } 9 \mathrm{~V} \text { ] }\end{array}$ & 43.75 & 11 & 0 & - \\
\hline & $\begin{array}{l}\text { Capsular polysaccharide } \\
\text { biosynthesis protein } \\
\text { [serotype } 7 F \text { ] }\end{array}$ & 35.29 & 31 & & LGFIAGLI \\
\hline & $\begin{array}{l}\text { Capsular polysaccharide } \\
\text { biosynthesis protein } \\
\text { [serotype 6B] }\end{array}$ & 43.75 & 6 & 0 & - \\
\hline & $\begin{array}{l}\text { Capsular polysaccharide } \\
\text { biosynthesis protein } \\
\text { [serotype 5] }\end{array}$ & 29.76 & 20 & 1 & NSVAYS \\
\hline & $\begin{array}{l}\text { Capsular polysaccharide } \\
\text { biosynthesis protein } \\
\text { [serotype 1] }\end{array}$ & 35.29 & 30 & 2 & LGFIAGLI/ NSVAYS \\
\hline & $\begin{array}{l}\text { Capsular polysaccharide } \\
\text { biosynthesis protein } \\
\text { [serotype 4] }\end{array}$ & 35.29 & 23 & 1 & LGFIAGLI \\
\hline
\end{tabular}

gated vaccines (Polio, PCV10,) are identified in the $\mathrm{S}$ gene of the SARS-CoV-2 genome. Given the novel aspects of the importance of Hepatitis B, Streptococcus pneumoniae, and Polio immunities as potential protective factors in the COVID-19 pandemic, measures to organize mass immunization against these viruses should be strengthened. Vaccination with attenuated viruses may explain partially the low symptomatic infection rate among children as there are other factors yet to be considered.

\section{Conclusions}

The main of this work is tracking the effect of existing vaccines against COVID-19 threats using suitable computational techniques. As a conclusion, our obtained results indicate that some antigenic proteins in these investigated vaccines may protect against severe COVID19. We suggest that these types of vaccines can reduce the risk of COVID-19 mortality, but we note that this silico study must be confirmed using in vitro analysis. 


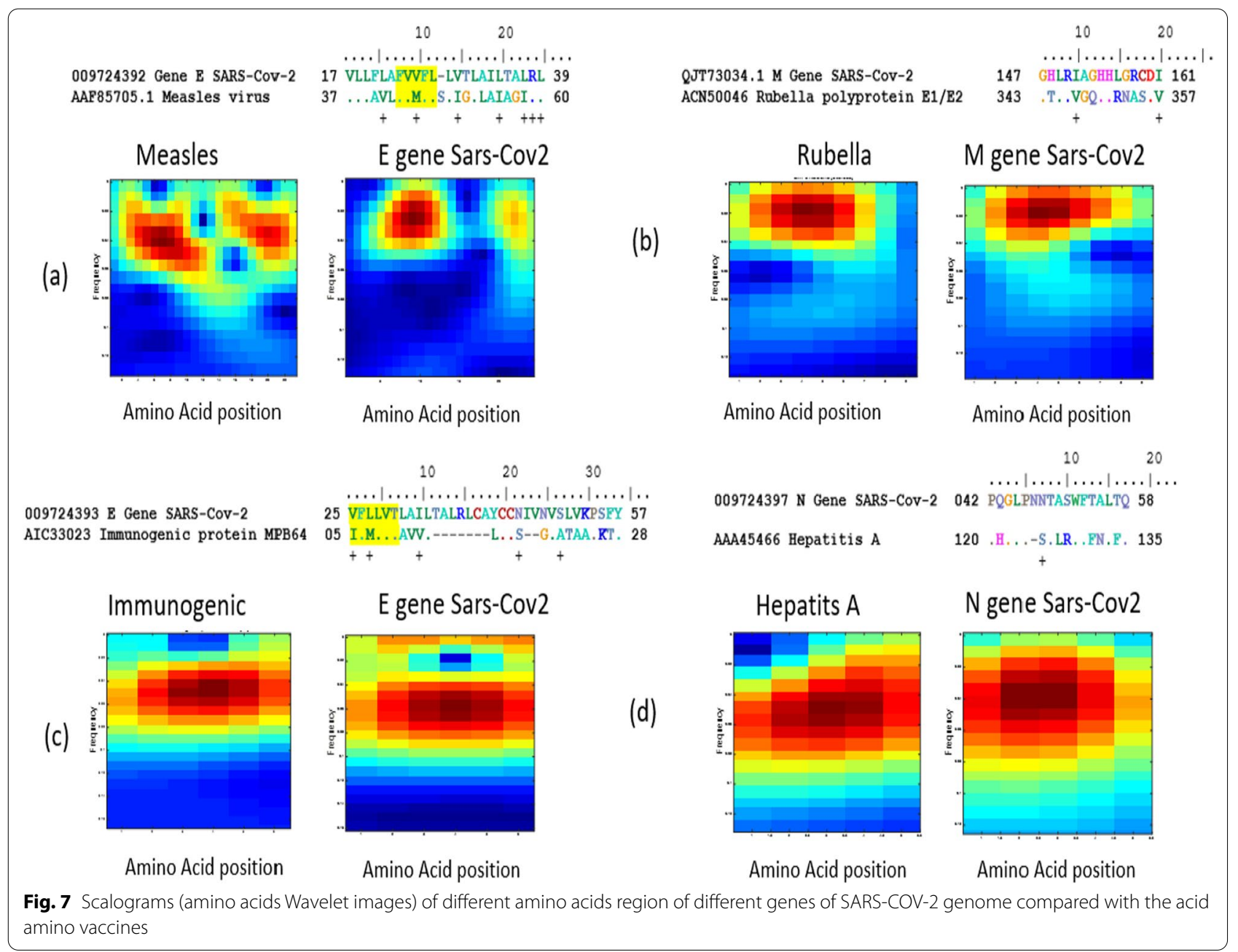

\section{Abbreviations}

CoV: Coronaviruse; Covs: Coronaviruses; COVID-19: Coronavirus disease 2019; SARS-CoV-2: Severe acute respiratory syndrome coronavirus 2; S: Spike; ORFs: Open reading frames; MMR: Measles, mumps, and rubella; BCG: Bacillus Calmette-Guérin; OPV: Oral poliovirus vaccine; HIB: Hemophilus influenzae type-B; CWT: Continuous wavelet transform; EllP: Electron ion interaction potential; PCV10: Streptococcus pneumonia; NCBI: National Center for Biotechnology Information; WHO: World Health Organization; BLAST: Basic local alignment search tool; Blastp: Protein blast.

\section{Acknowledgements}

The authors are thankful to the co-authors for their support to complete the manuscript. We are also thankful to the anonymous reviewers for their perceptive comments on the manuscript.

\section{Author's information}

Dr. Rabeb Touati obtained a Ph.D. in electrical engineering from the National Engineering School of Tunisia (ENIT). Currently, she has a Postdoctoral position at the Laboratory of Human Genetics (LR99ES10) at the Faculty of Medicine of Tunis (FMT). Her research interest includes genomic signal processing, bioinformatics, pattern recognition and machine learning.

Dr. Ahmed A. Elngar is Associate Professor of Computer Science at the Faculty of Computers and Artificial Intelligence, Beni-Suef University, Egypt. Dr. AE he is also, Associate Professor of Computer Science at College of Computer Information Technology, American University in the Emirates, United Arab Emirates. Dr. AE is the Founder and Head of Scientific Innovation Research
Group (SIRG). Dr. AE is a Director of the Technological and Informatics Studies Center (TISC), Faculty of Computers and Artificial Intelligence, Beni-Suef University. Dr. AE has more than 55 scientific research papers published in prestigious international journals and over 25 books covering such diverse topics as data mining, intelligent systems, social networks and smart environment. Dr. AE is a collaborative researcher He is a member in Egyptian Mathematical Society (EMS) and International Rough Set Society (IRSS). His other research areas include Internet of Things (loT), Network Security, Intrusion Detection, Machine Learning, Data Mining, Artificial Intelligence. Big Data, Authentication, Cryptology, Healthcare Systems, Automation Systems. He is an Editor and Reviewer of many international journal around the world. Dr. AE won several awards including the Young Researcher in Computer Science Engineering", from Global Outreach Education Summit and Awards 2019, on 31 January 2019 (Thursday) at Delhi, India. Also, he awards Best Young Researcher Award (Male) (Below 40 years)", Global Education and Corporate Leadership Awards (GECL-2018), Plot No-8, Shivaji Park, Alwar 301001, Rajasthan.

\section{Authors' contributions}

Dr. RT designed the study, Dr. RT and Dr. AE wrote the main text and contributed to carry out analysis and to prepare figures, and Dr. RT validated the study. Dr. RT and Dr. AE read and approved the final manuscript.

\section{Funding}

This study was funded by the Tunisian Ministry of Higher Education and Scientific Research (Research laboratory: LR99ES10). 


\section{Availability of data and materials}

All data generated or analyzed as part of this study are included in this published article.

\section{Declarations}

\section{Ethics approval and consent to participate}

This study did not include Human participants or Patient data. Hence no ethical approval and consent to participate is required.

\section{Consent for publication}

Not applicable. This study did not include patients.

\section{Competing interests}

The authors declare that they have no competing interests.

\section{Author details}

'LR99ES10 Human Genetics Laboratory, Faculty of Medicine of Tunis (FMT), University of Tunis El Manar, Tunis, Tunisia. ${ }^{2}$ BIOPOLE Society, 63 Av. Hbib Bourguiba, Tunis, Tunisia. ${ }^{3}$ Faculty of Computers and Artificial Intelligence, Beni-Suef University, Slah Salem Str., 62511 Beni-Suef City, Egypt. ${ }^{4}$ American University in the Emirates, 503000, Dubai Intl. Academic City, Dubai, United Arab Emirates.

Received: 10 August 2021 Accepted: 17 February 2022

Published online: 07 March 2022

\section{References}

1. Zhou P, Yang XL, Wang XG, Hu B, Zhang L, Zhang W et al (2020) A pneumonia outbreak associated with a new coronavirus of probable bat origin. Nature 579(7798):270-273

2. Coronaviridae Study Group of the International Committee on Taxonomy of $V$ (2020) The species severe acute respiratory syndrome-related coronavirus: classifying 2019-nCoV and naming it SARS-CoV-2. Nat Microbiol 5(4):536-44

3. Li G, De Clercq E (2020) Therapeutic options for the 2019 novel coronavirus (2019-nCoV). Nat Rev Drug Discovery 19(3):149-150

4. Cui J, Li F, Shi ZL (2019) Origin and evolution of pathogenic coronaviruses. Nat Rev Microbiol 17(3):181-192

5. Masters PS, Perlman S (2013) Coronaviridae. Fields Virol 1:825-858

6. Wu F, Zhao S, Yu B, Chen YM, Wang W, Song ZG et al (2020) A new coronavirus associated with human respiratory disease in China. Nature 579(7798):265-269

7. Touati R, Haddad-Boubaker S, Ferchichi I, Messaoudi I, Ouesleti AE, Triki $\mathrm{H}$ et al (2020) Comparative genomic signature representations of the emerging COVID-19 coronavirus and other coronaviruses: High identity and possible recombination between Bat and Pangolin coronaviruses. Genomics. 112:4189-4202

8. Hedman HD, Krawczyk E, Helmy YA, Zhang L, Varga C (2021) Host diversity and potential transmission pathways of SARS-CoV-2 at the human-anima interface. Pathogens 10(2):180

9. WHO. Coronavirus disease (COVID-19) weekly epidemiological update 2020 [22 October 2020]. Available from: https://www.who.int/emerg encies/diseases/novel-coronavirus-2019/situation-reports.

10. Riggioni C, Comberiati P, Giovannini M, Agache I, Akdis M, Alves-Correia M et al (2020) A compendium answering 150 questions on COVID-19 and SARS-CoV-2. Allergy 75(10):2503-2541

11. Curtis N, Sparrow A, Ghebreyesus TA, Netea MG (2020) Considering BCG vaccination to reduce the impact of COVID-19. Lancet. https://doi.org/10. 1016/S0140-6736(20)31025-4

12. Hamiel U, Kozer E, Youngster I (2020) SARS-CoV-2 rates in BCG-vaccinated and unvaccinated young adults. JAMA. https://doi.org/10.1001/jama. 2020.8189

13. Escobar LE, Molina-Cruz A, Barillas-Mury C (2020) BCG vaccine protection from severe coronavirus disease 2019 (COVID-19). Proc Natl Acad Sci USA. https://doi.org/10.1073/pnas.2008410117

14. Haddad-Boubaker S, Othman H, Touati R, Ayouni K, Lakhal M, Mustapha IB et al (2020) In silico comparative study of SARS-CoV-2 proteins and antigenic proteins in BCG, OPV, MMR and other vaccines: evidence of possible putative protective effect

15. Faust L, Huddart S, MacLean E, Svadzian A. Universal BCG vaccination and protection against COVID-19: critique of an ecological study. April 1, 2020 https://naturemicrobiologycommunity.nature.com/users/36050-emilymaclean/posts/64892-universal-bcgvaccination-and-protection-again st-covid-19-critique-of-an-ecological-study (Accessed April 5, 2020).

16. Mysore V, Cullere X, Settles ML, Ji X, Kattan MW, Desjardins M et al (2021) Protective heterologous $T$ cell immunity in COVID-19 induced by the trivalent MMR and Tdap vaccine antigens. Med 2(9):1050-1071

17. Lassi ZS, Naseem R, Salam RA, Siddiqui F, Das JK (2021) The impact of the COVID-19 pandemic on immunization campaigns and programs: a systematic review. Int J Environ Res Public Health 18(3):988

18. Li WX (2020) Worldwide inverse correlation between Bacille CalmetteGuérin immunization and COVID-19 morbidity and mortality. Research Square

19. O'Neill LA, Netea MG (2020) BCG-induced trained immunity: can it offer protection against COVID-19? Nat Rev Immunol 20(6):335-337

20. Sidiq KR, Sabir DK, Ali SM, Kodzius R (2020) Does early childhood vaccination protect against COVID-19? Front Mol Biosci 7:120

21. Pawlowski C, Puranik A, Bandi H, Venkatakrishnan AJ, Agarwal V, Kennedy R, O'Horo JC, Gores GJ, Williams AW, Halamka J et al (2020) Exploratory analysis of immunization records highlights decreased SARS-CoV-2 rates in individuals with recent non-COVID-19 vaccinations. medRxiv

22. Root-Bernstein R (2020) Possible cross-reactivity between SARS-CoV-2 proteins, CRM197 and proteins in pneumococcal vaccines may protect against symptomatic SARS-CoV-2 disease and death. Vaccines 8(4):559

23. Pawlowski C, Puranik A, Bandi H, Venkatakrishnan AJ, Agarwal V, Kennedy $R$ et al (2021) Exploratory analysis of immunization records highlights decreased SARS-CoV-2 rates in individuals with recent non-COVID-19 vaccinations. Sci. Rep. 11(1):1-20

24. Chahed MK, Bellali H, Alaya NB, Ali M, Mahmoudi B (2013) Auditing the quality of immunization data in Tunisia. Asian Pac J Tropic Disease 3(1):65-70

25. Rao KD, Swamy MNS (2008) Analysis of genomics and proteomics using DSP techniques. IEEE Trans Circuits Syst I Regul Pap 55(1):370-378

26. Touati R, Messaoudi I, Oueslati AE, Lachiri Z (2019) Distinguishing between intra-genomic helitron families using time-frequency features and random forest approaches. Biomed Signal Process Control 54:101579

27. Touati R, Tajouri A, Mesaoudi I, Oueslati AE, Lachiri Z, Kharrat M (2021) New methodology for repetitive sequences identification in human $X$ and $Y$ chromosomes. Biomed Signal Process Control 64:102207

28. Touati R, Messaoudi I, Oueslati AE, Lachiri Z (2019) A combined support vector machine-FCGS classification based on the wavelet transform for Helitrons recognition in C. elegans. Multimed Tools Appl 78(10):13047-13066

29. Vasilarou M, Alachiotis N, Garefalaki J, Beloukas A, Pavlidis P (2021) Population genomics insights into the first wave of COVID-19. Life 11(2):129

30. Baruah C, Devi P, Sharma DK (2020) Sequence analysis and structure prediction of SARS-CoV-2 accessory proteins 9b and ORF14: Evolutionary analysis indicates close relatedness to bat coronavirus. BioMed Res Int 2020:1-13

31. Kostinov MP, Zhuravlev PI, Gladkova LS, Mashilov KV, Polishchuk VB, Shmitko AD, Zorina VN, Blagovidov DA, Pahomov DV, Vlasenko AE, Ryzhov AA, Khromova EA (2021) Comparative analysis of the measles antibody levels in healthy medical personnel of maternity ward and women in labor. Front Immunol 12:680506. https://doi.org/10.3389/ fimmu.2021.680506

32. Sajuni S (2020) Vaksinasi Measles, Mumps, dan Rubella (MMR) Sebagai Prophylaxis Terhadap COVID-19. KELUWIH : Jurnal Kesehatan dan Kedokteran 1(2):25-28

33. Fidel PL Jr, Noverr MC (2020) Could an unrelated live attenuated vaccine serve as a preventive measure to dampen septic inflammation associated with COVID-19 infection. MBio 11(3):e00907-e920

34. Franklin R, Young A, Neumann B, Fernandez R, Joannides A, Reyahi A, Modis Y (2020) Homologous protein domains in SARS-CoV-2 and measles, mumps and rubella viruses: preliminary evidence that MMR vaccine might provide protection against COVID-19. MedRxiv

35. Karadeniz A, Alaşehir EA (2020) Seroepidemiology of hepatitis viruses, measles, mumps, rubella and varicella among healthcare workers and 
students: should we screen before vaccination. J Infect Public Health 13(4):480-484

36. Itatani T, Horiike R, Nakai H, Taira K, Honda C, Shirai F, Konishi K (2021)

Model comparisons of the cost effectiveness of rubella vaccination method in Japanese adults. Vaccines 9(3):233

37. Li Y, Tenchov R, Smoot J, Liu C, Watkins S, Zhou Q (2021) A comprehensive review of the global efforts on COVID-19 vaccine development. ACS Cent Sci 7(4):512-533

\section{Publisher's Note}

Springer Nature remains neutral with regard to jurisdictional claims in published maps and institutional affiliations.

\section{Submit your manuscript to a SpringerOpen ${ }^{\circ}$ journal and benefit from:}

- Convenient online submission

- Rigorous peer review

- Open access: articles freely available online

High visibility within the field

- Retaining the copyright to your article

Submit your next manuscript at $>$ springeropen.com 